\title{
Giangiacomo $\mid$ The Relationship Between Architecture Martines and Mathematics in the Pantheon
}

An examination of the latest Pantheon studies illustrates the newest theories of relationships between architecture and mathematics in Rome's most celebrated building. This paper was presented at the Nexus 2000 conference on architecture and mathematics, 4-7 June 2000, Ferrara, Italy. Many studies on the Pantheon are carried out far from Rome and so ideas on the monument cannot be checked easily or frequently. For this reason, a group of architects and archaeologists are working in Rome, trying to resolve some seemingly banal but still unanswered questions. For instance, one question that is often asked is: Could the inside of the Pantheon have been an astronomical observatory?

Over the last fifteen years, publications, archaeological excavations and restoration work have changed our traditional view of the Pantheon. Under the direction of Paola Virgili, the Rome Town Council Archaeology Office has recently excavated the piazza where the Pantheon is situated and the State Office for Monuments has begun restoration of the rotunda, under the direction of Mario Lolli Ghetti and Giovanni Belardi. The 18th century restoration work on this monument, with its fine marbles and colours, is the subject of a book by Susanna Pasquali. Archaeological excavation and restoration have provided objective data on which to base our observations.

In 1986 Godfrei and Hemsoll [Godfrei and Hemsoll 1986] put forward a new theory on the original function of the monument: "an imperial audience chamber". Subsequently, Hemsoll, Davies and Wilson Jones [Hemsoll, Davies and Wilson Jones 1987] published a plausible hypothesis on the size of the pronaos in the original design. In Das Pantheon in Rom, Abbild und Mass des Kosmos [Sperling 1999], Gert Sperling analysed the whole monument in terms of first century $\mathrm{AD}$ mathematics and gnomonics. Although the most important works we have on the architecture and understanding of the Pantheon remain those by De Fine Licht [De Fine Licht 1968] and MacDonald [MacDonald 1976], Sperling's book revolutionizes our knowledge of the monument in terms of its relation to neoplatonic mathematics. It is not easy to follow on from Sperling with new arguments and his book requires careful and meditated reading.

Sperling has carried on from where Herman Geertman left off in his celebrated study, "AEDIFICIVM CELEBERRIMVM, studio sulla geometria del Pantheon" [Geertmann 1980]. Sperling's conclusions also make use of previous works by Jacobson [Jacobson 1986]; Alvegård [Alvegård 1987]; Haselberger [Haselberger 1995]; Williams [Williams, 1997]. It is as if Sperling is taking a "peripatetic stroll" inside the monument in the company of all these writers, with me tagging along behind, a little boy led by the hand, with the work I wrote in 1989 [Martines 1989]. Sperling's book has several merits which I wish to underline: 
- Almost all the mathematical relationships among the lines and points of the monument are visible to the naked eye.

- The floor on which we walk is a mathematical abacus, which we measure with our steps and, again with our eyes, appreciate its shapes and proportions, this time with a little help from Kim Williams.

- The monument is an allegory of the cosmos, but it must be seen in relation to another building in Rome: the Mausoleum of Augustus in the Campus Martius. Here we are indebted to Edmund Buchner, who excavated the Horologium Solarium Augusti under the block of houses between Piazza del Parlamento and Piazza San Lorenzo in Lucina.

- The analemma, which is used in constructing sundials, is applied by Sperling on the section of the Pantheon and, thus pinpoints some architectonic lines that look as though they have been arranged according to the declination of the sun at the solstice and the equinox. We know of gnomonics applied to architecture in another geometrical monument, Castel del Monte [Tavolaro 1981.]

I do not wish to list all those who have written on the Pantheon after De Fine Licht. I will mention only Howard Saalman [Saalman 1988] and William Loerke [Loerke]. In effect a rational bibliography on the Pantheon would be a very useful publication. It would certainly include Rodolfo Lanciani [Lanciani 1897] and especially Antonio Michetti and Fabrizio Esposito [Esposito and Michetti 1996], respectively professor and disciple in the science of construction, for breaking new ground in their study on the reconstruction of the proportionment of the dome structure by means of classical geometry; unfortunately literary sources are silent on this subject. We know from Hero of Alexandria about the statics of columns and architraves, but there is nothing from that period on vaults.

Many studies on the Pantheon are carried out far from Rome and so ideas on the monument cannot be checked easily or frequently. For this reason, together with a group of architects and archaeologists working in Rome, I thought it might be a good idea to try and resolve some seemingly banal but still unanswered questions:

- What is the exact orientation of the Pantheon?

- What is its topographic position with respect to the Mausoleum of Augustus and to the preexisting buildings, adjacent to the Pantheon?

- What path does the sun follow on the lacunaria at midday at the solstice and the equinox?

- Have there been any variations in astronomical coordinations since the year $150 \mathrm{AD}$ ?

- Which stars can be seen at night through the eye of the dome, during the course of the seasons?

In charge of this programme is Riccardo Migliari, professor of the Department of Representations and Reliefs at the Rome University "La Sapienza". Working in collaboration with him are Mark Wilson Jones of Bath University, Matthias Bruno of Rome University "La Sapienza", Cinzia Conti of the Rome Archaeological Office and Giovanni Belardi, Director of the Pantheon. There will be a web site for the data so that it may be utilized also by those far from Rome. I hope Prof. Migliari will be able to present these results here, at Nexus IV, next year. Gert Sperling has given his full backing to the project, and has suggested taking weekly readings of the sun at the same time on the Rome meridian. 
A question that is often asked is: Could the inside of the Pantheon have been an astronomical observatory? The Golden House of Nero was another building which was architecturally inspired by the sun and, according to Suetonius, the main hall, a rotunda, revolved day and night according to the motion of the earth; but it was definitely not an astronomical observatory. This aspect has been discussed by D'Onofrio. [D'Onofrio 1992.] However I think the eye of the Pantheon is too small to be an astronomical observatory and too large to be a gnomonic hole; in San Petronio, Bologna, for example, the gnomonic hole of the meridian is only $27 \mathrm{~mm}$ wide. Moreover, in the history of gnomonica scientia, the discovery of the use of a ray of light passing through a hole is attributed to Ibn Yunis, a Muslim astronomer active in Cairo and who died in 1009 AD. However D'Onofrio's theory is stimulating and next year we hope to have some precise answers. Mathematical analysis of architecture is scientific by definition. The method is scientific because it is based on numbers and theorems, but the result is not always scientific because we cannot repeat an experiment the way it was done by Galileo Galilei: we cannot always be certain that a mathematical observation we make corresponds to historical fact, that is, the intention of constructing a building according to a mathematical rule that modern research may have discovered. We must be honest with historians working with Latin and Greek, who put their trust in mathematicians, methods used in philology and logic being so similar. In order to clarify matters I would like to suggest adopting certain criteria, at least with regard to ancient architecture, which is where my everyday work lies.

1. Mathematics can be used to describe any physical experience, but often the equation is not a law, like the laws of Galileo on the Pendulum and falling bodies, but only a mathematical representation of a reality that escapes us. In our field this is true of proportions in plan and elevation.

2. Proportions and numbers should be verified on the monument itself, not on scale drawings. Autoptic inspection, that is, personal observation with the naked eye, is indispensable for evaluating the state of measurement points, instrumental errors and construction material.

3. Studies which are applied to historical facts must make use of sources as documentary proof of an intention.

4. When there are no direct sources we must refer to treatises and scientific knowledge concerning the architecture we are observing.

5. In ancient architecture proportions and numbers must be evident and easily perceived by the eye. I must mention here the work of Maria Teresa Bartoli on the drawing of the lacunaria of the Pantheon, 1995, and Mark Wilson Jones on the Arch of Constantine, 1995. Both Wilson Jones and I are indebted to Heinrich Bauer for the importance of this criteria of visibility of proportions in ancient architecture. Our culture, in this respect, is still that of the Renaissance, as if we were all pupils of Luca Pacioli: it is a seed of the Renaissance that lives in our humanistic civilisation and we must be aware of this when we study ancient architecture, which, precisely because of this, is Classical but not Renaissance.

Nexus Network Journal - Volume II, 2000 
After having formulated these criteria I feel like Lucian's Menippus, the cynic-philosopher, who, in the Dialogues of the Dead, desecrates the myths of Olympus and the behaviour of men. For this reason people called him $\tau o v \kappa v v \alpha$ (tòn kùna), the dog that bites with irony.

Lucian, who was in Rome at the time of Hadrian, wrote famous descriptions of works of art; in fact he is considered the founder of art criticism and a particular literary genre, the $\varepsilon \kappa \phi \rho \alpha \sigma \iota \sigma$ (ekphrasis), which, in fact, means description. One of these descriptions is entitled The Room and is about architecture and oratory. Lucian's room is not that of any particular building but a model room: it is rectangular, apsidal, facing the east; "the relationship between length and width and between these and height is harmonious". Lucian speaks of "invincible pleasure to the eyes" and says that "words decorate" architecture, and in so doing underlines the risks of art criticism. Moreover, Lucian maintains that architecture and oratory are aimed at "the common man" and "the cultured man". Towards the end of the Classical world, similar criteria of aesthetics can be found in Procopius, who wrote On the Buildings of the Emperor Justinian. For these writers, architecture is a complex organism, which unites matter and ideas in an aesthetic perception that is harmonious, not divided, as it is for us moderns, into humanistic perception and geometrical perception. On the other hand, it is true that in the Classical world mathematics is aesthetics; mathematicians used similes taken from architecture: Nicomachus of Gerasa, a contemporary of Hadrian, uses bridges and ladders to explain how mathematics leads to epistemology.

The exceptional flowering of mathematical studies on the Pantheon is due to its eminent architecture and the shapes of its interior space: it is the greatest example in the world, $\pi \varepsilon \rho \mathrm{c}$ $\sigma \phi \alpha \iota \rho \alpha \sigma \kappa \alpha \iota \kappa v \lambda \iota v \delta \rho \circ v$ (perì sphaìras kài kulìndru), of Archimedes's sphere and cylinder, that is, one inscribed in the other. In antiquity, these shapes helped students learn Archimedes' universal law, $4 / 3 \pi r^{3}$. Archimedes had these shapes inscribed on his tomb, where Cicero was to see them; but man walks inside the sphere and cylinder of the Pantheon, like in the кoб $\mu \omega$ (kòsmo): a Greek word with three meanings: "order"; "beauty"; "world". This is a summary of the work I wrote in 1992, but this is not my aim here. In studies on works of art, gnosiology always surpasses ontology; that is, the problem of the knowledge of something surpasses its reality. We have more studies on the significance of the Pantheon than on its structure: for example, our knowledge of the dome is still based on Piranesi's etchings and observations made by Alberto Terenzio in the thirties.

The boom in mathematical studies on the Pantheon is also due to a quality of mathematics: an important theorem generates numerous corollaries, not always known to the mathematician who advanced that theorem. Most modern critics attribute the design of the Pantheon to one of the world's greatest architects, Appollodorus of Damascus, who was also a famous mechanical engineer; this is thanks to the work of Wolf Dieter Heilmeyer, and the great archaeologists before him.

First published in the NNJ online July 2000

\section{Acknowledgment}

I thank my English teacher, Fred Moffa of the British Institute of Rome, for his translation. 


\section{References}

AlVEGÅRD, L. 1987. The Pantheon Metrological System - a consistent, anthropometrical, time-calendar system based on golden section approximation ratios. Billdal: Chalmers University of Technology.

Bartoli, Maria Teresa. 1994. Scaenographia vitruviana: il disegno delle volte a lacunari tra rappresentazione e costruzione. Disegnare. Idee. Immagini 9/10: 51-62.

Esposito, Fabrizio And Antonio Michetti. 1996. Il Pantheon: Teoria e tecnica della commodulatio. Disegnare. Idee. Immagini 13: 69-80.

De Fine Licht, KJelD. 1968. The Rotunda in Rome. Jutland Archaeological Society Series, viii. Copenhagen: Gyldendalske Boghandel, Norkisk Forlag.

D'OnOfrio, Cesare. 1992. In Gli Obelischi di Roma, 1992. [need full reference]

GeErTman, Herman. 1980. AEDIFICIVM CELEBERRIMVM, studio sulla geometria del Pantheon. Bulletin Antieke Beschaving 55: 203-229.

Godfrey, P. And D. Hemsoll. 1986. The Pantheon: Temple or Rotunda? In Pagan Gods and Shrines of the Roman Empire, ed. M. Henig and A. King, pp. 195-209. Oxford: Oxford University Committee for Archaeology.

Haselberger, L. 1995. Ein Leibelriss der Vorhalle des Pantheon. Die Werkrisse von dem Augustusmausoleum. Roemische Mitteilungen des Dt. Arch. Instituts 101: 279-308.

Hemsoll, D., P. Davies and M. Wilson Jones. 1987. The Pantheon: Triumph of Rome or Triumph of Compromise. Art History 10:133-153.

JaCOBSOn, D.M. 1986. Hadrianic Architecture and Geometry. American Journal of Archaeology 90.

LANCIANI, R. 1897. The Ruins and Excavations of Ancient Rome.

LOERKE, William C. A Rereading of the Interior Elevation of Hadrian's Rotunda. Journal of the Society of Architectural Historians 49: 22-43.

MacDonald, William L. 1976. The Pantheon: Design, Meaning and Progeny. London: Allen Lane.

Martines, GiAngiaCOMO. 1989. Argomenti di geometria antica a proposito della cupola del Pantheon. Quaderni dell'stituto di Storia dell'Architettura 13: 3-13.

Saalman, Howard Saalman. 1988. The Pantheon Coffers: Pattern and Number. Architectura 18: 122-123.

Sperling, Gert Sperling. Das Pantheon in Rom, Abbild und Mass des Kosmos. Neuried: Vers Una Verlag,1999.

TAvolaro, Aldo. 1984. Una stella sull Murgia. Coelum LII (November-December 1984): 327-354.

Williams, Kim. 1997. Il Panteon e la creazione dell'universo. Lettera Matematica Pristem 24 (June 1997): 4-9.

\section{The Author}

Giangiacomo Martines, architect with the Soprintendenza Archeologica of Rome, directed the restoration of Column of Trajan and the Column of Marcus Aurelius (1981-1988), about which he has published several essays (including an forthcoming essay in La colonne Aurélienne, John Scheid and Valerie Huit, eds., Biblioteque des Hautes Etudes, in print). He is now responsible for the restoration of the Flavian Amphitheatre. He studied art in Sicily under the direction of Federico Zevi. He has also published on the Palazzo Ducale di Gubbio (Convegno su Federico da Montefeltro, Urbino, 1982); the science of the gromatici (land surveyors) (in Misurare la terra, exhibit catalogue, Rome, 1985); the Pantheon in Rome (in Quaderni dell'stituto di Storia dell'Architettura, 1992). He contributed to the Trattato di restauro architettonico, directed by Giovanni Carbonara (Utet, 1996). His current studies concern the poliorcetica of Apollodorus of Damascus and the mechanics of Heron of Alexandria (in L'arte dell'assedio di Apollodoro di Damasco, Adriano La Regina, ed., Electa, 1999, and the Annali di architettura, 10-11, 1998-1999). 